\title{
The Outcome of Multimodality on Language Teaching and Learning
}

\author{
Miladiyah, Universitas Airlangga, Surabaya
}

\begin{abstract}
Multimedia-based learning is becoming increasingly common. Despite its limitations, and certainly should not be seen as a substitute for face-to-face interaction, it does have many advantages for professional teacher development. ICT's have introduced new instructions that we use to think. New identities that are connected to communication tools are born. From the applied linguistics point of view, we are specifically interested in the implication that these communicative skills can have on the processes of language production and interpretation. There are many changes in conceptions of language and communication that have affected the school communities and the relationships established between teachers and students made possible by digital online communications. This review of literature discusses the issues of ICT in language teaching, multimedia-based learning and its principles, CALL, and multimodality learning. The review of the literature will determine how multimodal models affect the teaching and learning processes and show the outcome.
\end{abstract}

Keywords: CALL;ICT; multimedia-based learning; multimodal learning

\section{Introduction}

Today, Indonesian citizen experience a fast changing lifestyle related to information and communication technology (ICT) utility, such as gadget and internet. The last few decades have witnessed emergence of new technologies and a diverse array of media we communicate. Today the way we live and communicate often includes print along with use of email, texting, voicemail, and Internet web-pages with image, sound, and music. Eventually, the notion of "text" has broadened to include digitally constructed texts constituted through more than one modes or means of representation such as words, dynamic and static images, sounds, symbols and gestures. These texts are dynamic, nonlinear and interactive. To be able to function in today's world, a shift is required in literacy training from the conventional sense towards producing and understanding texts involving different modes of human communication such as visual, verbal and gestural (Harste, Woodward \& Burke 1984; Leu, 2002).

Information and Communications Technologies (ICT) provides academics with an opportunity to create rich learning environments for their students, enhanced by the wealth of information and resources on the Internet, as well as the inclusion of a range of multimedia-based learning elements. Multimodal courses involve the use of multimedia and ICT to develop dynamic course resources that appeal to different sensory modes and a variety of learning styles (Sankey $\&$ Birch, 2005). This strategy leads learners to perceive that it is easier to learn, improve attention rates, and improve learning performance. There are marked differences in both computer skills and cognitive skills among learners that these technologies are bringing about. ICT have introduced new tools that we use to think; consequently, the ways in which we think would also change (Sankey, 2006).

We are specifically interested in the impacts of these technologies on the processes of language production and interpretation. In this paper, the writer discusses The issue of ICT in language teaching, multimedia learning and its principles, CALL and multimodality learning. A review of the literature will determine how multimodal models affect the teaching and learning processes and show the outcome.

\section{ICT in language teaching}

Now, ICT (Information and Communication Technology) has been used in almost all fields of life, including in education. Computer technology has become so essential that the 
government put ICT as one of the curriculum in Indonesia's education. The utilization of ICT in education has recently started to appeal the potential and significant progress in language teaching. As Hartoyo (2008) stated in his book, a computer is a tool and medium that facilitates people in learning a language, although the effectiveness of learning depends totally on the users. Hartoyo (2008) also asserts that English language teaching has been shaped by the search for the 'one best method' of teaching the language. Regardless of the teaching objectives, the attempts of the teaching profession have been shaped by a desire to find 'a' better way of teaching than the existing method.

According to Pete Sharma and Barney Barret (2007), there are several reasons for using technology in language teaching. In addition to the fact that technology can be motivating, it offers the possibility to work autonomously or interact and collaborate with others. Technology also provides instant feedback on language performance in various tasks and exercises. Technology can also be an extension of the classroom and can be time saving. Finally, technology can promote language learning with fresh authentic and motivating materials directly usable from the Internet.

\section{Multimedia-based learning and its principles}

Multimedia has been successfully applied to many courses in order to provide a wide variety of learning styles or modalities (Birch \& Gardiner, 2005). Learning styles are defined as characteristic cognitive, affective, and physiological behaviors that serve as relatively stable indicators of how learners perceive, interact with, and respond to the learning environment. Learners are more comfortable learning in an environment which reflects their predominant learning style (Sankey, 2006). Some learners have a preferred learning modality, namely, visual, aural, read/write or kinesthetic and many other learners are multimodal (use a combination of these modalities). Multimedia can be used to develop a more inclusive curriculum that appeals to visual, aural and kinesthetic learners and overcome differences in student performance that may result from different learning styles. Presenting material in a variety of modes has been used to encourage students to develop a more versatile approach to learning (Morrison, Sweeney, \& Heffernan, 2003).

Technology provides more ways to represent concepts through different media formats. Such advances in technology ask for pedagogical enquiries to confirm the usefulness of such new activities in facilitating learning. Learners who have access to multiple representations enhance their comprehension, learning, memory, communication and inference (Scaife \& Rogers, 1996). Kozma (1991) argues that learners will benefit more if the instructional methods provide, perform or model cognitive operations that are important to the task and the situation. Learners will benefit more if they can perform or provide for themselves the operations provided by these representational media (Kozma, 1991). Providing the learner with a sound structure and content is more important than providing them with interactivity and animation afforded by new media. Comprehension and learning require a sound content and structure of instructional material, and not new media or types of representation. The combination of text and image is effective when the information provided is complementary and adapted to each presentation. Making connections from multiple representations depend not only on the presentation mode and the construction of the interrelations between the multimodal items but also on the characteristics of the task (Dubois \& Vial, 2000).

Some of the most important principles of multimedia learning identified and how they contribute to student learning are summarized in the table below:

Table 1: Principles of multimedia learning

\begin{tabular}{|l|l|l|}
\hline No & \multicolumn{1}{|c|}{$\begin{array}{c}\text { The principles of } \\
\text { Multimedia Learning }\end{array}$} & \multicolumn{1}{c|}{ The contribution to student learning } \\
\hline 1 & $\begin{array}{l}\text { Words and pictures are better } \\
\text { than words alone. }\end{array}$ & $\begin{array}{l}\text { People learn better from words and pictures than from } \\
\text { words alone (Mayer, 2005). Words include written and } \\
\text { spoken text, and pictures include static graphic images, }\end{array}$ \\
\hline
\end{tabular}


Table 1, cont.

\begin{tabular}{|c|c|c|}
\hline & & $\begin{array}{l}\text { animation and video. The use of both words and pictures } \\
\text { lets the brain processes more information in working } \\
\text { memory (Sweller, 2005). Mayer (2005) tells us that } \\
\text { narration and video is much more effective than narration } \\
\text { and text. }\end{array}$ \\
\hline 2 & $\begin{array}{l}\text { Multimedia learning is more } \\
\text { effective when learners' } \\
\text { attention is focused. }\end{array}$ & $\begin{array}{l}\text { Multimedia applications are more effective when } \\
\text { learner's attention is not split. Split attention occurs when } \\
\text { the learner is forced to attend to information that is far } \\
\text { apart, such as when content is visually far apart on the } \\
\text { screen or if it is presented at two separate points in time. } \\
\text { When related content is presented together in time } \\
\text { visually, learning is more effective (Mayer, 2005). When } \\
\text { related content is not presented together, learner attention } \\
\text { is split and the brain has more work to do to integrate the } \\
\text { disparate sources of information. Words and pictures } \\
\text { presented simultaneously are more effective than when } \\
\text { presented sequentially (Mayer \& Sims, 1994). }\end{array}$ \\
\hline 3 & $\begin{array}{l}\text { The presentation of } \\
\text { multimedia content should } \\
\text { exclude extraneous and } \\
\text { redundant information. }\end{array}$ & $\begin{array}{l}\text { Multimedia learning is most effective when it includes } \\
\text { only content that is relevant and aligned to the } \\
\text { instructional objectives (Mayer, 2003). Kalyuga, } \\
\text { Chandler and Sweller (1999) found that students learned } \\
\text { more when extraneous and redundant information was } \\
\text { not included in a multimedia presentation. Learning is } \\
\text { most effective when irrelevant information is eliminated } \\
\text { because of the brain's limited information processing } \\
\text { resources. }\end{array}$ \\
\hline 4 & $\begin{array}{l}\text { Multimedia learning is more } \\
\text { effective when it is } \\
\text { interactive and under the } \\
\text { control of the learner }\end{array}$ & $\begin{array}{l}\text { Not all students learn at the same pace. Research tells us } \\
\text { that when learners are able to control the pace of the } \\
\text { presentation they learn more. Multimedia presentations } \\
\text { are more effective when the learner has the ability to } \\
\text { interact with the presentation, by slowing it down or by } \\
\text { starting and stopping it. This pacing can also be achieved } \\
\text { by breaking the presentation into segments; shorter } \\
\text { segments that allow users to select segments at their own } \\
\text { pace work better than longer segments that offer less } \\
\text { control (Mayer, 2003). }\end{array}$ \\
\hline 5 & $\begin{array}{l}\text { Multimedia learning is more } \\
\text { effective when learner } \\
\text { knowledge structures are } \\
\text { activated prior to exposure } \\
\text { to multimedia content. }\end{array}$ & $\begin{array}{l}\text { Learning from multimedia presentations is enhanced } \\
\text { when the structures for organizing the information are } \\
\text { activated (Pollock, Chandler, \& Sweller, 2002). Helping } \\
\text { students recall or acquire structures that will help them } \\
\text { organize and understand the information can be } \\
\text { accomplished in several ways. Activation can be } \\
\text { accomplished by allowing students to preview the } \\
\text { content through demonstrations, discussion, directed } \\
\text { recall and written descriptions. These preview activities } \\
\text { should be directed at activating prior knowledge } \\
\text { (Kalyuga, 2005), signaling what is important, and } \\
\text { showing how the content is organized. Activating } \\
\text { knowledge helps provide a structure from long term } \\
\text { memory to understand and organize the new information } \\
\text { from working memory. }\end{array}$ \\
\hline
\end{tabular}


Table 1, cont.

\begin{tabular}{|c|c|c|}
\hline 6 & $\begin{array}{l}\text { Multimedia instruction that } \\
\text { includes animation can } \\
\text { improve Learning. }\end{array}$ & $\begin{array}{l}\text { When used effectively, animated content can improve } \\
\text { learning. Animation appears to be most effective when } \\
\text { presenting concepts or information that students may } \\
\text { have difficulty envisioning. Animation is more effective } \\
\text { when students have the ability to start and stop the } \\
\text { animation and view it at their own pace or are able to } \\
\text { manipulate various facets of the animation. Animation is } \\
\text { more effective if it is accompanied by narration, which } \\
\text { makes use of both the auditory and visual channels } \\
\text { (Mayer \& Chandler, 2001). }\end{array}$ \\
\hline 7 & $\begin{array}{l}\text { Multimedia leaning is most } \\
\text { effective when the learner is } \\
\text { engaged with the } \\
\text { presentation. }\end{array}$ & $\begin{array}{l}\text { Multimedia is most effective when the content and } \\
\text { format actively engage the learner. Active engagement } \\
\text { helps the student construct knowledge and organize } \\
\text { information into meaningful schema (Mayer, 2003). } \\
\text { Multimedia that is more personalized engages learners } \\
\text { more than multimedia that is less personalized (Mayer, } \\
\text { 2005). Presentations that have a more conversational } \\
\text { tone tend to be more engaging than those that have a } \\
\text { more formal tone. Presentations that use the more } \\
\text { familiar -you and I- are more engaging than those that } \\
\text { present in the third person (Mayer, 2005). Learners tend } \\
\text { to find presentations that use a familiar voice with a } \\
\text { familiar accent more engaging than those that use a less } \\
\text { familiar voice and accent (Mayer, Sobko \& Mautone, } \\
\text { 2003). }\end{array}$ \\
\hline 8 & $\begin{array}{l}\text { Multimedia learning is most } \\
\text { effective when the learner } \\
\text { can apply their newly } \\
\text { acquired knowledge and } \\
\text { receive feedback. }\end{array}$ & $\begin{array}{l}\text { Multimedia is most likely to be effective when students } \\
\text { are provided with opportunities to apply what they have } \\
\text { learned following exposure (Mayer, 2005). This } \\
\text { reinforces and strengthens the newly acquired } \\
\text { knowledge. Students should be provided with } \\
\text { opportunities to integrate what they have learned with } \\
\text { their everyday life. Feedback is an important part of the } \\
\text { learning process. It is important to provide learners with } \\
\text { clear feedback about their progress on an ongoing basis } \\
\text { (Gee, 2005). Feedback helps keep students informed } \\
\text { about their progress and helps them stay engaged. } \\
\text { Providing feedback can reinforce what has been learned } \\
\text { and can also correct any misconceptions (Gee, 2005). }\end{array}$ \\
\hline
\end{tabular}

\section{Computer Assisted Language Learning (CALL)}

Computer-assisted language learning (CALL) is a form of computer-based learning which carries two important features: individualized learning and bidirectional learning. CALL materials are used in teaching to facilitate the language learning process. It is a form of studentcentered learning materials, which promote self-paced accelerated learning. CALL is not a software application, but rather courseware that is designed for language learning for a specific group of learners. The philosophy of CALL puts a strong emphasis on student-centered lessons that allow the learners to learn on their own using structured and/or unstructured interactive lessons. CALL can also be used as remedial to help learners with limited language proficiency (Warschauer, 2008). The reasons for using Computer-assisted Language Learning include: (a) experiential learning, (b) motivation, (c) enhancement of student achievement, (d) authentic 
materials for study, (e) greater interaction, (f) individualization, (g) independence from a single source of information, and (h) global understanding (Warschauer, 2008).

\section{Multimodal learning}

The concept of multimodality begins with the understanding that language is but one of the communicative resources through which meaning is (re)made, distributed, and interpreted (Jewitt, 2008; see also Kress \& van Leeuwen, 2001).

Multiple representations provide some advantages for learners to learn. Learning is not only a visual-cognitive activity but also a physical one particularly as it requires the interplay among multiple sensory modalities and representations. The literature is mainly talking about visual and linguistic representations which are beneficial for specific tasks but they might not be appropriate for the whole spectrum of the learning activities. Learning is closely related to experiencing life and in life we employ all of our senses not just vision. For learners to be engaged into a subject, they need to relate themselves and connect their everyday life to the learning material; in other words, they need to be situated. Such relationships could be generated by following an alternative approach to learning: one that incorporates learners' multiple modalities and the available instruments of the environment including the multiple representations provided by books or multimedia software. Such an approach is argued to be multimodal learning (Daniels, 2001).

\section{The outcome of multimodality in language learning and teaching and how it affects them}

A multimodal approach to the classroom highlights the important use of multiple modalities in real learning environments. Children select or negotiate the meanings conveyed from modalities to construct conceptions about the world. Each modality contains information that is a resource for pupil's meaning construction. Each modality covers a different aspect of phenomena which could challenge prior conceptions of the world and provide resources to imagine and think with (Kress \& van Leeuwen, 2001). According to Kress and van Leeuwen, (2001), teachers often use gestures together with speech to draw attention to images and other references within the classroom. In particular, they argue: a variety of modes are interacting and interplaying: gestures, drawings, speech, objects. Each mode contributes to meaning construction: speech to create a difference, an image on the whiteboard to get a visual backdrop, manipulation of an object to locate the discussion in the physical setting, action to make clear the dynamic nature of the concept, the image in the textbook to do a stable summary, cohesion is achieved through repetition, synchronization, similarity and contrast. The selection of modes makes meaning: the metaphorical path will be different in each case. Each mode plays a different role in the construction of the entity at hand. Each mode requires the pupils to do a different type of work in order to understand (Kress \& van Leeuwen, 2001).

Moreno and Mayer (2007) believe that multimodal learning environments use different modes to represent content knowledge, for example verbal and non-verbal, where the non-verbal mode is the pictorial mode including both static and dynamic graphics. These different presentation modes (verbal and non-verbal) are used to appeal to students ${ }^{6}$ different sensory modalities (visual and auditory). Further, Multimodal courses allow instructional events or elements to be presented in more than one sensory modes (multiple representations), thus have been used to further facilitate student's learning (Shah \& Freedman, 2003). The development of technology enhanced courses may result in a more current and relevant curriculum, innovation and new ideas, enhanced course quality, and diversification of academic programs (Maguire, 2005). ICT has significantly changed the way that teaching, learning and assessment occur. For example, the adoption and integration of ICT may lead to more student-centered approaches to teaching and learning, and thus support a more constructivist approach to course design. This is primarily due to the non-linear design of learning environments that has been found to increase 
learners' control over the way they progress through their materials (Karagiorgi \& Symeou, 2005).

Research indicates that using multimodal texts contributes to students' use of cognitive skills and increases their creativity, attention, participation and production (Callow\& Zammit, 2012). Walsh (2010) suggests that the use of multimodal texts in language skills courses changes the nature of reading, writing, speaking and listening

skills. The use of multimodal texts not only changes in the process of teaching a class, testing and evaluation, participation in courses but also the roles of teachers and learners (Walsh, 2010). Introduction of hardware, software and the Internet does not guarantee technology integration to classrooms. The teachers need opportunities to make use of multimodal literacies in their own lives before integrating them effectively to their teaching practices (Lankshear \& Knobel, 2003). To this end, teacher training programs should involve knowledge and skills to integrate multimodal literacies to their practices.

\section{Conclusion}

Multimedia presentations compensate for absence of appropriate cognitive structures in certain domains due to the lack of opportunities that characterize certain communities and social groups and also compensate for the weak or incomplete development of verbal skills. A multidisciplinary approach is needed to understand the social, cognitive, cultural and linguistic variables involved in the process of language learning. The lines of research reviewed here can set the grounds for empirical investigations into the various arrangements and affordances that multimodality offers for the process of language learning. The quick pace of change from printbased to more visually oriented presentations of information involves a quick response from language teachers and educators to take advantage of multimodality to engage learners in meaningful cognitive, critical understandings. Attention to the meaning-making potential of the various multimodal designs can help language learners to cope more efficiently as they face new modes of information presentation.

\section{References}

Birch, D., \& Gardiner, M. 2005. Students' perceptions of technology-based marketing courses. Proceedings of Australia and New Zealand Marketing Educators Conference. Australia: Fremantle, 5-7

Callow, J \& Zammit, K. 2012. 'Where lies your text?': Engaging high school students from low socio-economic backrounds in reading multimodal texts. English in Australia, 47(2), 6977

Daniels, H. 2001. Vygotsky and pedagogy. London: Routledge.

Dubois, M., \& Vial, I. 2000. Multimedia design: The effects of relating multimodal information. Journal of Computer Assisted Learning, 16, 157-165.

Gee, J. P. 2005. Learning by design: Good video games as learning machines.E-Learning, (2), 516.

Harste J, Woodward V, Burke C. 1984. Language Stories and Literacy Lessons. Portsmouth, NH: Heinemann

Hartoyo. 2008. Individual differences in computer-assisted language learning. Semarang: Pelita Insani Semarang

Jewitt, C. 2008. Multimodality and literacy in school classrooms. Review of Research in Education, 32, 241-267.

Kalyuga, S. 2005. Prior knowledge principle in multimedia learning. In R. E. Mayer (ed.). The Cambridge Handbook of Multimedia Learning. New York: Cambridge University Press.

Kalyuga, S., Chandler, P. \& Sweller, J. 1999. Managing split attention and redundancy in multimedia instruction. Applied Cognitive Psychology, 13, 351-371.

Karagiorgi, Y., \& Symeou, L. 2005. Translating constructivism into instructional design: Potential and limitations. Educational Technology \& Society, 8 (1), 17-27.

Kozma, R. B. 1991. Learning with media. Review of Educational Research, 61, 179-211. 
Kress, G. R., \& van Leeuwen, T. 2001. Multimodal discourse: The modes and media of contemporary communication. London: Edward Arnold.

Leu, Jr., D. J. 2002. The New Literacies: Research on reading instruction with the Internet. In A. E. Farstrup, \& S. Samuels (eds.), WhatResearch Has to Say About Reading Instruction. Newark, DE: International Reading Association, 310-336.

Maguire, L. L. 2005. Literature review: Faculty participation in online distance education: Barriers and motivators. Online Journal of Distance Learning Administration, 8 (1).

Mayer, R. E. 2003. Learning and instruction. Upper Saddle River, NJ: Prentice Hall.

Mayer, R. E. 2005. Principles of multimedia learning based on social cues: Personalization, voice, and image principles. In R. E. Mayer, (Ed.) The Cambridge Handbook of Multimedia Learning. New York: Cambridge University Press.

Mayer, R. E., \& Chandler, P. 2001. When learning is just a click away: Does simple interaction foster deeper understanding of multimedia messages? Journal of Educational Psychology, 93, 390-397.

Mayer, R. E., Sobko, K., \& Mautone, P. D. 2003. Social cues in multimedia learning: Role of speakers voice. Journal of Educational Psychology, 95, 419-425.

Mayer, R. E., \& Sims, V. K. 1994. For whom is a picture worth a thousand words? Extensions of a dual-coding theory of multimedia learning. Journal of Educational Psychology, 86, 389-401.

Moreno, R., \& Mayer, R. 2007. Interactive multimodal learning environments. Educational Psychology Review, 19, 309-326.

Morrison, M., Sweeney, A., \& Hefferman, T. 2003. Learning styles of on-campus and off-campus marketing students: The challenge for marketing educators. Journal of Marketing Education, 25(3), 208-217.

Pollock, E., Chandler, P., \& Sweller J. 2002. Assimilating complex information. Learning and Instruction, 12, 61-86.

Sankey, M. D. 2006. A neomillennial learning approach: Helping non-traditional learners studying at a distance. The International Journal of Education and Development using Information and Communication Technology (IJEDICT), 2 (4), 82- 99.

Sankey, M., \& Birch, D. 2005. Researching transmodal delivery at USQ: Different horses for different courses. Paper presented at the New Researchers for New Times Conference. Queensland University of Technology, Brisbane. Australia.

Scaife, M., \& Rogers, Y. 1996. External cognition: How do graphical representations work?.International Journal of Human-Computer Studies, 45, 185-213.

Shah, P., \& Freedman, E. G. 2003. Visuospatial cognition in electronic learning. Journal of Educational Computing Research, 29 (3), 315-24.

Sharma, P. \& Barret, B. 2007. Blended learning: Using technology in and beyond the language classroom. Macmillan.

Sweller, J. 2005. Implications of cognitive load theory for multimedia learning. In R. E. Mayer (ed.).The Cambridge Handbook of Multimedia Learning. New York: Cambridge University Press.

Walsh M. 2010. Multimodal literacy: What does it mean for classroom practice? Australian Journal of Language and Literacy, 33(3): 211-239.

Warschauer, M. 2008. Computer assisted language learning: An introduction. Available at http://www.ict4lt.org/en/warschauer.htm. (Accessed 13 June 2018). 